\title{
Corrigendum: GABA signalling modulates plant growth by directly regulating the activity of plant-specific anion transporters
}

Sunita A. Ramesh, Stephen D. Tyerman, Bo Xu, Jayakumar Bose, Satwinder Kaur, Vanessa Conn,

Patricia Domingos, Sana Ullah, Stefanie Wege, Sergey Shabala, José A. Feijó, Peter R. Ryan \& Matthew Gilliham

Nature Communications 6:7879 doi: 10.1038/ncomms8879 (2015); Published 29 Jul 2015; Updated 28 Aug 2015

The original version of this Article contained a typographical error in the spelling of the author Matthew Gilliham, which was incorrectly given as Matthew Gillham. This has now been corrected in both the PDF and HTML versions of the Article.

(c) This work is licensed under a Creative Commons Attribution 4.0 International License. The images or other third party material in this article are included in the
article's Creative Commons license, unless indicated otherwise in the credit line; if the material is not included under the Creative Commons license, users will need to obtain permission from the license holder to reproduce the material. To view a copy of this license, visit http://creativecommons.org/licenses/by/4.0/ 